\title{
Influence of diets supplemented with naturally protected or unprotected eucalyptus oil on methane production and lactating buffalo productivity
}

Fawzy Mohamed Abo-Donia ( $\square$ framsis2nd@gmail.com )

Animal Production Research Institute (APRI), Agriculture Research Center (ARC), Egypt

https://orcid.org/0000-0003-2941-3629

Mohamed Youssif Elaref

Sohag University Faculty of Agriculture

Abd El-Moniem Ali Sayed Mahgoub

Animal Production Research Institute

Tarek Abd El Wahab Ahmed Deraz

Animal Production Research Institute

Usama Aboelez Nayel

Monufia University

\section{Research Article}

Keywords: Eucalyptus oil, eucalyptus leaves, eucalyptus seed capsules, methane, degradability, digestibility, milk production.

Posted Date: July 26th, 2021

DOl: https://doi.org/10.21203/rs.3.rs-721132/v1

License: (c) (i) This work is licensed under a Creative Commons Attribution 4.0 International License. Read Full License 


\section{Abstract}

This study aimed to investigate the effects of naturally protected eucalyptus oil supplementation in a form of leaves (EUL) or mature seed capsules (EUS) compared to crude eucalyptus oil (EUO). The control group $\left(G_{1}\right)$ received the basal diet consisting of concentrate feed mixture, fresh berseem, rice straw, and corn silage. The $G_{2}, G_{3}$, and $G_{4}$ animals were fed the basal diet with a supplement of $200 \mathrm{~g} / \mathrm{head} /$ day of EUL or EUS or $4 \mathrm{~mL}$ EUO, respectively. Supplementation with EUL or EUS increased $\mathrm{NH}_{3}-\mathrm{N}, \mathrm{SCFA}$, and acetic acid concentrations in-vitro. The total count of bacterial, protozoa and cellulolytic bacteria increased $(P<0.05)$ with EUL and EUS supplementation. Methane production lowered $(P<0.05)$ with EUS, $E U L$, and EUO supplementation. Milk fat decreased $(P<0.05)$ with EUO supplementation, while an adverse trend was shown for lactose. No differences in feed conversion were found among EUS, EUL, and EUO. Total protein, albumin, and blood urea increased $(P<0.05)$ with supplementation of EUL or EUS compared to EUO. EUO supplementation yielded increased $(P<0.05)$ AST, ALT, glucose, and creatinine. Supplementation with EUL, EUS, or EUO decreased $(P<0.05) D M, O M$, and $C P$ digestibility. While digestibility of EE with supplementation by EUL, EUS, or EUO was higher $(P<0.05)$. Digestibility of NDF and ADF decreased $(P<0.05)$ with supplemental EUL, EUS, or EUO compared to the control diet. Feeding EUS increased the values of TDN and DCP compared to EUL, which was higher than EUO. Our results confirm that the naturally protected form of leaves or seeds mitigates the negative effects of directly supplementing crude eucalyptus oil.

\section{Highlights}

- Caution is recommended when adding eucalyptus supplementation (Leaves, Seeds capsulated, or crude oil) because it affects animal performance.

- Eucalyptus oil that is naturally protected in a form of leaves or seed capsules mitigates the negative effects of supplemented crude oil on nutrient digestibility, feeding value.

- Although crude eucalyptus oil reduces methane production, the milk production and composition compared reduces compared using naturally protected oil in a form of leaves or seed capsules.

- Supplementation of eucalyptus (Leaves, seeds capsulated, or crude oil) in buffalo feed did not seem to have a protective effect on organ function associated with the blood measurements tested in this study.

\section{Introduction}

The rumen is a complex ecosystem in which nutrients consumed by microorganisms at a suitable $\mathrm{pH}$ provide the main products of fermentation, short-chain fatty acids (SCFAs), and microbial biomass, which are used by the host ruminants (Cieslak et al. 2013; Vakili et al. 2013). Recently, there has been increased interest in reducing the rate of rumen methane production. Methane $\left(\mathrm{CH}_{4}\right)$ production from enteric fermentation is of concern worldwide because of the increased accumulation of greenhouse gases in the atmosphere as well as the waste of nutritious energy (Sallam et al. 2010). There has been an interesting 
effort to reduce $\mathrm{CH}_{4}$ release by inhibition of ruminal methanogens to increase the efficiency of feed energy utilization by ruminants; this would also improve economic efficiency and the environment (Benchaar and Greathead 2011). Many studies have been conducted to investigate the effects of supplementation with eucalyptus leaves and eucalyptus oil (EUO) on methane production (Mclntosh et al. 2003; Castillejos et al. 2006) however, much is still unknown about using dried or ground mature seeds. Additionally, (Sallam et al. 2010) hypothesized that EUO could be used as a feed supplement to alter rumen biohydrogenation to reduce $\mathrm{CH}_{4}$ release and increase the flow of volatile acids (VA) to the duodenum. Moreover, Abo-Donia and Nagpal (2015) reported that tannins have been shown to alter rumen biohydrogenation, while Sallam et al. (2010) stated that eucalyptus has an ionophore effect by affecting VA formation in the rumen through inhibition of the final step in the biohydrogenation of VA to stearic acid. Due to the volatile and reactive nature of essential oils (ESOs), it is possible that their effectiveness, when included in an animal's diet, possibly altered by conditions during the production season as well as storage of ESOs and conditions in the digestive system of the animals (Nguyen et al. 2009).

A recent study by Chouhan et al. (2017) showed that the use of ESOs in a protected form has a high potential for antimicrobial resistance owing to the increased chemical stability and solubility, reduced rapid evaporation, and reduced degradation of the active ESOs. In addition, Lammari et al. (2020) demonstrated that the encapsulation of ESOs to make their release subject to continuous control enhances their bioavailability and effectiveness against microbes.

In recent years, due to increasingly negative consumer perceptions, there has been increasing interest in adding ESOs to ruminant feeds to increase milk production and improve the animals' physiological performance (Thao et al. 2015). In the same line, Turek and Stintzing (2013) suggested that adding such oils in their natural form, whether in the form of leaves or grains, avoids the negative effects of those crude oils and increases their effectiveness in ruminant nutrition. However, knowledge is scarce about the effects of using naturally protected as opposed to crude oil on animal performance (Maes et al. 2019). Therefore, this study aimed to investigate the effect of supplementation of eucalyptus crude oil vs naturally protected in form (leaves or seeds capsules) on methane production and productive performance.

\section{Materials And Methods}

\section{Ingredients and the experimental diets}

Eucalyptus leaves (EUL) and green mature seed capsules (EUS) collected from trees on beach canals were dried under shade for a week, and then ground and stored at ambient room temperature until use. Eucalyptus oil (EUO) was obtained from El Hawag for Natural Oils, El Nasr City, Cairo, Egypt. Four experimental diets were formulated as total mixed ration isonitrogenous and isocaloric diets to cover the recommended requirements of lactating buffalo according to Kearl (1982). Animals in the first group $\left(\mathrm{G}_{1}\right)$ received the basal diet consisting of concentrate feed mixture (CFM), fresh berseem (FB), rice straw (RS), 
and corn silage (CS) at a 40:60 concentrate: roughage ratio. The second $\left(G_{2}\right)$, third $\left(G_{3}\right)$, and fourth $\left(G_{4}\right)$ groups were fed the basal diet with a supplement of $200 \mathrm{~g} / \mathrm{head} /$ day of EUL, EUS, or $4 \mathrm{~mL}$ EUO, respectively. Supplemental EUL, EUS, or EUO were dissolved daily in $1 \mathrm{~L}$ tap water, and then blended and mixed directly with the concentrated feed to ensure consistency. Weekly homogeneous samples of experimental diets were dried and ground, and then held in glass bottles for analysis and in vitro studies. The chemical composition of ingredients and the experimental diets are presented in Table 1.

\section{Animals and management}

A total of 16 healthy lactating Egyptian buffalo (body weight: $457.4 \pm 10.5 \mathrm{~kg}$; in season: 2 to 4 ; after 14 days in lactation) were divided into four similar groups and randomized according to their previous milk records using quadratic $4 \times 4$ Latin square experimental designs. Animals were individually fed the experimental diets twice daily ( 8 a.m. and 6 p.m.). The diet was offered for $28 \mathrm{~d}(21 \mathrm{~d}$ as a preliminary period $+7 \mathrm{~d}$ as a collection period), and it was adjusted every week based on changes in body weight and milk production. Mineral salt blocks were supplied for the animals to lick freely, along with access to drinking water.

\section{In vitro gas production and degradability}

The in vitro gas production technique was conducted according to Theodorou et al. (1994) on obtained samples of the experimental diets. Rumen fluid was collected from two buffalo cows in each group before the morning meal using a stomach tube. About $600 \mathrm{mg}$ of tested sample $(1.0 \mathrm{~mm})$ was incubated with $60 \mathrm{~mL}$ of previously prepared buffered rumen fluid for each bottle $(1: 3 \mathrm{~mL} / \mathrm{mL})$ according to Goering and Van Soest (1970) under continuous $\mathrm{CO}_{2}$ reflux in a $100 \mathrm{~mL}$ calibrated glass bottle in a water bath maintained at $39^{\circ} \mathrm{C}$. Samples were incubated in quadratic groups together with four bottles containing only an incubation medium (blank). Headspace gas pressure was measured at 2, 4, 8, 16, 24, 36, and 48 h. The kinetic parameters of GP( $\mathrm{t})(\mathrm{mL} / \mathrm{g} D M)$ were fitted using the NLIN option according to France et al. (2000) as:

\section{$G v_{(t)}=b \times\left(1 e^{-c(t-L)}\right)$,}

where $\mathrm{Gv}_{(t)}$ is the gas produced at time $t$, " $b$ " is the asymptotic gas produced ( $\left.\mathrm{mL} / \mathrm{g} \mathrm{DM}\right)$ by the insoluble but slowly fermenting fraction, " $c$ " is the constant gas production rate $(\mathrm{mL} / \mathrm{h})$, " $t$ " is the time of fermentation, and "L" is lag time. In vitro $\mathrm{CH}_{4}$ production was determined as described by Pellikaan et al. (2011).

After termination of the incubation, the bottle contents were used for the determination of in vitro neutral detergent fiber degradability (IVNDFD). In vitro liquor from each bottle was collected after filtration to determine the $\mathrm{pH}$ using a portable $\mathrm{pH}$ meter, the concentration of $\mathrm{NH}_{3}-\mathrm{N}$ according to AOAC (2016), and the total SCFAs according to Eadie et al. (1967). Molar proportions of acetic, propionic, and butyric concentrations were analyzed using gas-liquid chromatography (GC 2010, PerkinElmer) capillary column (HPINNOWAX, 30m_0.250 mm_0.25 mm). The counting of rumen ciliate protozoa was performed under a 
light microscope according to Dehority (2003). Bacteria and cellulolytic bacteria were counting according to Wanapat et al. (2000).

\section{Digestibility and blood parameters}

The feces were collected directly from the rectum of all animals in each group once in the morning before feeding at the end of the collection period. Acid-insoluble ash (AIA) was used as an internal marker to estimate the digestibility of nutrients (Van Keulen and Young 1977). Feeds and fecal samples were dried at $60^{\circ} \mathrm{C}$ and ground to pass through a $1 \mathrm{~mm}$ screen for analysis. Dry matter (DM), crude protein (CP), ash, and ether extract (EE) determined according to the procedure of AOAC (2016). Neutral detergent fiber (NDF) was estimated according to Van Soest et al. (1991). Nutrient digestibility coefficients and the nutritive value were calculated from the equation given by Schneider and Flatt (1975).

$$
\text { DM digestibility }(\%)=100-\frac{100 \times \text { AIA } \% \text { in feed }}{\text { AIA } \% \text { in feces }}
$$

Digestibility of components $=100-\quad \underline{100 \times A I A} \%$ in feed $\times$ component $\%$ in feed

AIA $\%$ in feces $\times$ component $\%$ in feces

Blood samples were obtained in the morning from the jugular vein of each animal in the experimental groups before access to feed on the final day of the collection period. Blood samples were centrifuged at $4000 \mathrm{rpm} / 15 \mathrm{~min}$ to separate the serum and then stored at ${ }^{-} 18^{\circ} \mathrm{C}$ until analysis. Total proteins, albumin, urea nitrogen (BUN), aspartate aminotransferase (AST), alanine aminotransferase (ALT), creatinine, and glucose concentration were determined using commercial kits (Bio Merieux 69280 Marcy-1, Etoile/France), according to the manufacturer's instructions.

\section{Milk production and composition}

Lactating buffalo cows were milked twice daily (6:00 and 18:00), and milk production (MP) was recorded for each buffalo during the collection period. Daily milk samples were mixed according to the diet of the morning and afternoon milk yield for each animal and stored at $20^{\circ} \mathrm{C}$ for analysis of milk protein, fat, and lactose using infrared Milko-Scan (133BN Foss Electric, Denmark). Ash was determined according to AOAC (2016), while total solids (TS) and solid not fat (SNF) were calculated as differences. Fat-corrected milk (FCM, 7\%) was calculated according to Raafat and Saleh (1962) using the following equation:

$\mathrm{FCM}=[(0.265 \times$ milk yield, $\mathrm{kg})+(10.5 \times$ fat yield, $\mathrm{kg})]$

The yield of energy-corrected milk (ECM) was calculated using fat and protein (adjusted to 3.5\% fat and $3.2 \%$ protein) by Casasús et al. (2004) as the following formula: 
$\mathrm{ECM}(\mathrm{kg})=$ milk production $(\mathrm{kg}) \times(383 \times$ fat $\%+242 \times$ protein $\%+783.2) / 3140$.

\section{Statistical analysis:}

Data of In vitro gas production kinetics were analyzed using Statistical Analytical System (version 9.2; SAS Institute, Cary, NC) according to the General Linear Model as follows:

$Y_{i j}=\mu+T_{i}+e_{i j,}(1)$

where: $Y_{i j}=$ observation; $\mu=$ overall mean; $T_{i}=$ the fixed effect of the treatments; and $e_{i j}=$ random error term common for all observations.

All obtained data from the feeding experiments were subjected to analysis of variance according to a $4 \times$ 4 Latin square design using the general linear model procedures of the Statistical Analysis System Institute (version 9.2; SAS Institute, Cary, NC). The model was:

$Y_{i j k l}=\mu+P_{i}+C_{j}+T_{k}+e_{i j k l}(2)$

where $Y_{i j k l}$ is the dependent variable under examination, $\mu$ is the overall mean, $P_{i}$ is the fixed effect of the period $(i=4), C_{j}$ is the random effect of the cow $(j=4), T_{k}$ is the fixed effect of the dietary treatments $(k=$ $4)$, and $e_{i j k l}$ is the random error. The results are presented as mean values with the standard error of the means. Differences among means at $P<0.05$ were accepted as representing statistical differences. Treatment means were compared by orthogonal polynomials by Duncan (1955) New Multiple Range Test.

\section{Results}

\section{In vitro gas production kinetics and fermentation patterns}

Data of leaves, seeds, and eucalyptus oil supplementation on in vitro cumulative gas, methane production, and NDF degradability are shown in Table (2). The $\mathrm{pH}$ value of the in-vitro incubated diet in $\mathrm{G}_{4}$ was increased $(P<0.05)$ significantly compared to the other experimental diets. The $\mathrm{NH}_{3}-\mathrm{N}, \mathrm{SCFAs}$, and acetic acid concentrations were decreased $(P<0.05)$ significantly in $\mathrm{G}_{4}$ as compared to $\mathrm{G}_{1}, \mathrm{G}_{2}$, and $\mathrm{G}_{3}$. The propionic acid concentrations of incubated rumen liquor in $\mathrm{G}_{2}$ and $\mathrm{G}_{3}$ were increased $(P<0.05)$ significantly compared to $\mathrm{G} 4$ and $\mathrm{G}_{1}$. The butyric acid concentrations of incubated rumen liquor in $\mathrm{G}_{3}$ were increased $(P<0.05)$ significantly compared to $\mathrm{G}_{1}, \mathrm{G}_{2}$, and $\mathrm{G}_{4}$. However, the $\mathrm{C}_{2} / \mathrm{C}_{3}$ ratio was decreased $(P<0.05)$ significantly in $\mathrm{G}_{2}$ and $\mathrm{G}_{3}$ compared to $\mathrm{G}_{4}$ and $\mathrm{G}_{1}$. The present study showed that EUO supplemented with buffalo diets led to an alteration in the end products of rumen fermentation with a drop in acetate.

Supplementation of EUO to the in vitro incubated diet in $\mathrm{G}_{4}$ led to a reduction $(P<0.05)$ in the total count of bacteria and cellulolytic bacteria compared to $\mathrm{G}_{2}, \mathrm{G}_{3}$, or $\mathrm{G}_{1}$. The total count of bacteria was not 
significantly different in $\mathrm{G}_{1}, \mathrm{G}_{2}$, and $\mathrm{G}_{3}$, but the cellulolytic bacteria count was lower $(P<0.05)$ in $\mathrm{G}_{3}$ than in $\mathrm{G}_{1}$. Conversely, the protozoa count was significantly increased $(P<0.05)$ with EUO supplementation $\left(\mathrm{G}_{4}\right)$ compared to supplementation with $\mathrm{EUL}\left(\mathrm{G}_{2}\right)$, EUS $\left(\mathrm{G}_{3}\right)$, or the control $\left(\mathrm{G}_{1}\right)$.

As illustrated in Fig. (1), the cumulative gas volume (calculated as means for all incubation times) was significantly lower $(P<0.05)$ for all treated diets $\left(G_{2}, G_{3}\right.$, and $\left.G_{4}\right)$ than for the control $\left(G_{1}\right)$. The lowest volume of gas produced was recorded with EUO $\left(\mathrm{G}_{4}\right)$, followed by in vitro incubated diets with EUL $\left(\mathrm{G}_{2}\right)$ and EUS $\left(G_{3}\right)$ (Table 2). The values of insoluble but slowly fermenting fraction (b) and constant gas production rate $(\mathrm{c})$ were significantly $(P<0.05)$ higher with EUO supplementation $\left(\mathrm{G}_{4}\right)$ compared to the other experimental diets. Otherwise, the lag time was significantly $(P<0.05)$ lower with EUO supplementation $\left(\mathrm{G}_{4}\right)$ compared to the other experimental diets. All studied supplements (EUL, EUS, or EUO) led to a significant decrease $(P<0.05)$ in methane production and degradability of IVNDFD compared to the control diet. The findings of this study show that all supplemented forms of eucalyptus decreased $(P<0.05)$ methane and total gas production.

\section{Feeding trials}

As shown in Table 3, supplementation of eucalyptus (EUS, EUL, or EUO) to buffalo diet led to a significant $(P<0.05)$ decrease in MP, 7\% fat-corrected milk (FCM), and energy-corrected milk (ECM) compared to the control diet. Buffalo in $\mathrm{G} 4$ had the lowest values of MP, 7\% FCM, and ECM, followed by buffalo in $\mathrm{G}_{2}$ and $\mathrm{G}_{3}$. Milk fat was significantly $(P<0.05)$ decreased in $\mathrm{G}_{4}$ compared to the other experimental groups. An adverse trend was obtained for the milk content of lactose, while the content of proteins, ash, SNF, and TS not affected $(P<0.05)$ significantly by supplementing EUS or EUL.

Feed conversion values identified as DMI/FCM, TDNI/FCM, and NI/FCM were increased $(P<0.05)$ significantly by either supplemental form of eucalyptus in experimental diets compared to the control. Supplementation with either EUL or EUS in $\mathrm{G}_{2}$ and $\mathrm{G}_{3}$ yielded preferred values of feed conversion compared to EUO supplementation in G4.

The data in Table 4, illustrate that supplementation of EUL, EUS, or EUO to the buffalo diet significantly ( $P$ $<0.05$ ) decreased the digestion coefficient of DM, OM, CP, NDF, and ADF compared to the control diet. Additionally, the digestion coefficients of these parameters were significantly $(P<0.05)$ higher in $\mathrm{G}_{2}$ and $\mathrm{G}_{3}$ than in $\mathrm{G}_{4}$. In contrast, the digestibility of $\mathrm{EE}$ in the experimental groups was increased $(P<0.05)$ significantly compared with the control group. The nutritive values were significantly $(P<0.05)$ affected by EUS, EUL, or EUO supplementation. Values of TDN for G3 and G4 were decreased $(P<0.05)$ significantly compared to $G_{1}$ and $G_{2}$, and $G_{4}$ had the lowest value of TDN. Data show that $G_{4}$ had the lowest value of $D C P$, followed by $G_{3}$ and $G_{2}$, respectively, and $G_{1}$ had the highest value of DCP.

Table 4 shows that serum total protein and albumin were significantly $(P<0.05)$ increased in $\mathrm{G}_{2}$ and $\mathrm{G}_{3}$ compared to $\mathrm{G}_{4}$ or $\mathrm{G}_{1}$, and $\mathrm{G}_{4}$ had the lowest level of serum total protein. In contrast, the concentrations 
of AST and ALT in the serum of buffalo cows fed a diet containing EUO $\left(\mathrm{G}_{4}\right)$ were significantly $(P<0.05)$ increased. In contrast, the concentrations of AST and ALT in the serum of buffalo cows fed a diet containing EUO $\left(\mathrm{G}_{4}\right)$ were significantly $(P<0.05)$ increased compared to the other experimental groups. The urea concentrations significantly differed between the supplementary groups and the control group. Serum urea was significantly $(P<0.05)$ decreased in $\mathrm{G}_{4}$ compared to the other experimental groups. Ruminal ammonia $\mathrm{N}$ over microbial requirements is absorbed across the rumen wall into the portal blood, and most of it is converted to urea in the liver. Serum glucose concentration was significantly $(P<0.05)$ affected by supplementation type. Buffalo cows in $\mathrm{G}_{4}$ had the highest serum glucose concentration, followed by buffalo cows in $G_{3}$ and $G_{2}$, respectively, and the lowest serum glucose concentration was estimated in buffalo cows in $\mathrm{G}_{1}$. Creatinine in buffalo cows fed a diet containing EUS or EUO were significantly $(P<0.05)$ increased compared to those fed a basal diet $\left(G_{1}\right)$ or a diet containing EUL $\left(G_{2}\right)$.

\section{Discussion}

\section{In vitro gas production kinetics and fermentation patterns}

The results of studies conducted on the supplementation of essential oils, especially eucalyptus, on in vitro rumen fermentation, and also the extent of their effect on the production of gases and methane, varied. Several results also showed a variation in the effect of these oils on the rate of degradability of nutrients components. The reduction in $\mathrm{pH}$ values with supplemental EUO in the diet during in vitro incubation in the current study was in line with the low rumen $\mathrm{pH}$ values observed in several previous studies (Sallam et al. 2010; Wang 2009 and Thao et al. 2014). Meanwhile, no effect on rumen pH was observed with EUL or EUS supplementation, which was in line with the results obtained by Thao et al. (2015); Manh et al. (2012). These results suggest that the use of supplemental eucalyptus oil that is naturally protected in the leaves or seed reduces the negative effects of supplemental eucalyptus crude oil.

Regarding ammonia concentration, the obtained result agreed with those of Vakili et al. (2013); Thao et al. (2015). A study by Castillejos et al. (2006) showed that long-term EUO supplementation led to a reduction in rumen ammonia N compared to the control diet. Moreover, Patra (2012) suggested that essential crude oils may inhibit bacterial production of excess ammonia in the rumen, resulting in reduced amino acid deamination and thus lowering rumen $\mathrm{NH}_{3}-\mathrm{N}$. Similarly, Mclntosh et al. (2003) demonstrated that EUO inhibited the growth of some hyper-ammonia-producing bacterial species (i.e., Clostridium sticklandii and Peptostreptococcus anaerobius), but other bacterial species such as Clostridium aminophilum were less sensitive. Hyper-ammonia-producing bacteria are present in low numbers in the rumen $(P<0.01)$ of the rumen bacterial population, but they have very high deamination activity (Castillejos et al. 2006). In the same line, Vakili et al. (2013) reported that high levels of EUO supplementation led to a slight reduction in concentrations of total SCFAs in the rumen. Similar findings were observed by Wang (2009) when EUO supplementation was used in the sheep diet.

Additionally, Mclntosh et al. (2003) reported that the effect of EUO supplementation in the rumen could be 
attributed to chemical structures and bioactive components. In the same context, Castillejos et al. (2006) and Giannenas et al. (2011) emphasized that EUO supplementation leading to alteration in the end products of rumen fermentation with a drop in acetate. The studies by Cobellis et al. (2015) found similar results to those obtained in this study, which indicated a decrease in feed degradability in the rumen. This could be attributed to the non-selective antimicrobial activities of supplemental ESOs, which affect a wide range of microbial subgroups such as cellulolytic bacteria. Furthermore, Patra and Yu (2012) found that supplementation of all the tested ESOs of clove, eucalyptus, garlic, oregano, and peppermint reduced the abundance of rumen archaea and protozoa; especially cellulolytic bacteria.

Along the same lines, Cieslak et al. (2013) stated that ESOs supplemented with ruminant diets could alter digestion and fermentation, and methanogenesis of diets in the rumen by microbial populations. Moreover, Sallam et al. (2010) suggested that the potential effect of supplementation with fresh and residual eucalyptus leaves on mitigation of in vitro $\mathrm{CH}_{4}$ production be attributed to a decrease in fermentable substrate rather than to a direct effect on methanogenesis. Analogous results were observed by Manh et al. (2012) in cows that received $100 \mathrm{~g} /$ day of eucalyptus leaf meal, which led to the mitigation of rumen $\mathrm{CH}_{4}$ emissions. The study by Patra and $\mathrm{Yu}$ (2012) reported a drop in methane production by less than $15 \%$ when using eucalyptus extract compared to the control group.

\section{Animal feeding and performance}

Several studies have implied the effect of supplemental eucalyptus leaves or eucalyptus oil on feed intake and palatability, but their results were variable and inconsistent (Ahmed et al. 2005). The results show that supplementing EUS, EUL, and EUO did not affect DMI. Similar findings were recorded by Benchaar et al. (2007) and Vakili et al. (2013), while Giannenas et al. (2011) stated that the amount of feed intake depends on the dose of ESOs supplemented. On the other hand, Cardozo et al. (2006) reported that EUO supplementation decreases DMI. The effects of eucalyptus supplementation on DMI may differ with the eucalyptus source, diet type, diet interactions, or adaptation of rumen microbial groups (Yang et al. 2010b). In another study, Sebei et al. (2015) reported that the major component of eucalyptus is 1,8-cineole, followed by a-pinene could be responsible for the degradation of the chemical constituent and also lead to the acceleration of oxidation. An increased feed conversion efficiency was observed when dairy cows were supplemented with eucalyptus leaf material (Thao et al. 2015) and also with eucalyptus oil (Giller et al. 2020; Al-Suwaiegh et al. 2020). Despite MP and ECM decreased with supplanting eucalyptus, the reverse result was recorded by Giannenas et al. (2011), who demonstrated an increase in MP with ESOs supplementation into the diets of dairy ewes. The effects of ESOs supplementation on the content of protein, fat, and lactose in the milk are very contradictory. Some studies have reported an increase in milk protein content (Wall et al. 2014), while others showed an increase in milk fat (Santos et al. 2010). Nevertheless, other studies have found an increase in milk lactose (Benchaar et al. 2007) when dairy cows and ewes diets are supplemented with ESOs.

The apparent digestibility of DM, OM, CP, NDF, and ADF differed $(P>0.05)$ among treatments in studies by Thao et al. (2014; 2015). Similarly, Sallam et al. (2010) concluded that supplementation with EUO 
influences the digestibility of DM and OM in-vitro. Furthermore, Santos et al. (2010) found that feed digestibility was affected when an ESOs compound was added to the diet of lactating dairy cows. The current results are supported by those obtained by Benchaar et al.(2007) who found that apparent total tract digestibilities of DM, CP, and NDF were affected in lactating cows supplemented with $2 \mathrm{~g} /$ day of ESOs.

In the present study, eucalyptus supplementation in buffalo diets led to changes in blood components Table 4. Meanwhile, Morsy et al. (2012) found that dietary supplementation with different ESOs (anise, clove, and juniper) or their combination significantly increased total protein, albumin, and globulin. In addition, Malekkhahi et al. (2015) demonstrated that sheep fed garlic ESOS or lambs fed a combined (thymol, carvacrol, eugenol, limonene, and cinnamaldehyde) supplemental diet did not affect plasma total protein and albumin. According to reviewed by Huang and Lee (2018) the improvement of serum protein of animals fed an ESOs blend could be due to the content of phytochemicals, which have immune stimulation and anti-inflammatory and antioxidative activities. Moreover, Yang et al. (2010b) reported that concentrations of some blood metabolites such as total protein and albumin could be influenced by the type of ESOs by changing the feed intake, and the lack of change in glucose and creatinine concentration may be attributable to lack of DMI alternation by the ESOs.

Therefore, the synthesis of urea in the liver is performed from ammonia absorbed from the rumen; as a result, urea $\mathrm{N}$ concentration in the blood is highly correlated with the rumen $\mathrm{NH}_{3}-\mathrm{N}$ concentration (Davidson et al. 2003). This interpretation is consistent with the results obtained, as the concentrations of rumen $\mathrm{NH}_{3}-\mathrm{N}$ (Table 2) were not affected by EUS and EUL supplementation compared with the EUO supplement, which was reflected in BUN. These results disagree with those obtained from Yang et al. (2010a), who investigated different doses of ESOs in beef cattle but were consistent with some of those obtained by Davidson et al. (2003). Moreover, supplementation of EUO in the finishing diet of calves was expected to have pharmacological activity; however, these compounds did not affect the liver enzymes. Many previous studies have found that supplementation with ESOs did not affect significantly blood glucose concentration (Vakili et al. 2013; Yang et al. 2010b). These findings agreed with Malekkhahi et al. 2015) who reported that glucose levels showed an alteration in the blood of growing lambs when supplementation of different ESOs or blends of them. However, Yang et al. 2010b) found an increase in the concentration of creatinine in the blood with the addition of eucalyptus leaves, eucalyptus oil, or ESOs blend to the diet compared to the control group (Al-Suwaiegh et al. 2020). In contrast, Castillo et al. (2012) reported that the ESOs blend (carvacrol, cinnamaldehyde, and capsaicin) supplementation decreased the serum creatinine level in calves.

\section{Conclusions}

Despite the ability of crude eucalyptus oil to reduce methane in the rumen of ruminants, it has negative effects on digestion and animal performance. The addition of camphor oil in the form of natural protection in the form of leaves or seed capsules mitigated the negative effects of adding the crude oil. The results indicated that the leaves followed by the seed capsules were better in their results compared 
to the addition of crude oil on digestion, milk production, and its components, as well as blood parameters.

\section{Declarations}

\section{Fundings}

Joint support between all of the following: Animal Production Research Institute; Faculty of Agriculture, Sohag University, and Faculty of Agriculture, Menoufia University, Egypt,

\section{Authors' contributions:}

Fawzy Abo-Donia: Conceptualization, Software, Writing - Original Draft, Writing - Review \& Editing, Visualization, Supervision. Usama Naye: Data curation, Methodology, Writing draft preparation. Mohamed Elaref: Methodology, Writing-Original draft preparation, Investigation. Abd El-Moniem Mahgoub: Conceptualization, Resources, Formal analysis, Visualization. Tarek Deraz: Software, Validation Investigation, Formal analysis.

Data availability (data transparency) The data that support the findings of this study are available from the corresponding author upon reasonable request.

Code availability (software application or custom code) Not applicable

Ethics approval All procedures and experimental protocols were carried out according to the guidelines for the care and use of animals in research and teaching per the ethical standards laid down in the 1964 Declaration of Helsinki and its later amendments.

Consent to participate All authors agree on their participation in the work herein reported.

Conflict of interest The authors declare no competing interests.

ptualization, Resources, Formal analysis, Visualization. Tarek Deraz: Software, Validation Investigation, Formal analysis.

\section{References}

Abo-Doni, F.M., and Nagpal, A.K., 2015. In vitro Evaluation of Moth (Phaseolus aconitifolius) Fodder, Khejri (Prosopis cineraria) Leaves and Their Combinations in Camel. Indian J. Anim. Nutr., 32 (2), 192197.

Ahmed, F.G., Yacout, M.H., and Abo-Donia, F.M., 2005. Effect of using Eucalyptus globulus leaves in growing rabbits diets. Egypt. J. Rabbit Sci., 15, 1-11. 
Al-Suwaiegh, S. B., Morshedy, S. A., Mansour, A. T., Ahmed, M. H., Zahran, S. M., Alnemr, T. M., and Sallam, S., 2020. Effect of an Essential Oil Blend on Dairy Cow Performance during Treatment and PostTreatment Periods. Sustainability, 12(21), 9123. https://doi.org/10.3390/su12219123.

AOAC, 2016. Official Methods of Analysis, 20th $\mathrm{Ed}$, (Association of Official Agricultural Chemists, Washington, USA), ISBN 13: 9780935584875.

Benchaar, C., Petit, H.V., Berthiaume, R., Ouellet, D.R., Chiquette, J., and Chouinard, P.Y., 2007. Effects of essential oils on digestion, ruminal fermentation, rumen microbial populations, milk production, and milk composition in dairy cows fed alfalfa silage or corn silage. Journal of Dairy Science, 90, 886-897, https://doi.org/10.3168/jds.S0022-0302(07)71572-2.

Benchaar, C, and Greathead, H., 2011. Essential oils and opportunities to mitigate enteric methane emissions from ruminants. Anim Feed Sci Technol., 166(167), 338-

355. https://doi.org/10.1016/j.anifeedsci.2011.04.024.

Cardozo, P.W., Calsamiglia, S, Ferret, A, and Kamel, C., 2006. Effects of alfalfa extract, anise, capsicum and a mixture of cinnamaldehyde and eugenol on ruminal fermentation and protein degradation in beef heifers fed a high concentrate diet. J Anim Sci., 84,2801-2808. https://doi.org/10.2527/jas.2005-593.

Casasús, I., Sanz, A., Villalba, D., Ferrer, R., and Revilla, R., 2004. Intake capacity of two breeds of suckler cattle of different milk yield potential and validation of prediction models. Livest. Prod. Sci., 89(2-3), 195-207 https://doi.org/10.1016/j.livprodsci.2004.02.003.

Castillejos, L., Calsamiglia, S., and Ferret, A., 2006. Effect of essential oils active compounds on rumen microbial fermentation and nutrient flow in in-vitro systems. Journal of Dairy Science, 89, 26492658. https://doi.org/10.3168/jds.S0022-0302(06)72341-4.

Castillo, C., Benedito, J.L., Vázquez, P., Pereira, V., Méndez, J., Sotillo, J., and Hernández, J. 2012. Effects of supplementation with plant extract product containing carvacrol, cinnamaldehyde and capsaicin on serum metabolites and enzymes during the finishing phase of feedlot-fed bull calves. Anim Feed Sci Technol., 171(2-4), 246-250. https://doi.org/10.1016/j.anifeedsci.2011.11.006.

Chouhan, S., Sharma, K., and Guleria, S., 2017. Antimicrobial activity of some essential oils-present status and future perspectives. Medicine, 4(3), 58. https://doi.org/10.3390/medicines4030058.

Cieslak, A., Szumacher-Strabel, M., Stochmal, A., and Oleszek, W., 2013. Plant components with specific activities against rumen methanogens. Animal, 7, 253-

265. https://doi.org/10.1017/S1751731113000852.

Cobellis, G., Petrozzi, A., Forte, C., Acuti, G., Orrù, M., Marcotullio, M.C., Aquino, A., Nicolini, A., Mazza, V., and Trabalza-Marinucci, M., 2015. Evaluation of the effects of mitigation on methane and ammonia 
production by using Origanum vulgare $L$. and Rosmarinus officinalis $L$. essential oils on in vitro rumen fermentation systems. Sustainability, 7(9), 12856-12869. https://doi.org/10.3390/su70912856.

Davidson, S., Hopkins, B.A., Diaz, D.E., Bolt, S.M., Brownie, C., Fellner, V., and Whitlow LW., 2003. Effects of amounts and degradability of dietary protein on lactation, nitrogen utilization, and excretion in early lactation Holstein cows. Journal of Dairy Science, 86,1681-1689. https://doi.org/10.3168/jds.S00220302(03)73754-0.

Dehority, B.A., 2003. Rumen microbiology. Nottingham, UK: Nottingham University Press, (Vol. 372). http://www.worldcat.org/oclc/474310570.

Duncan, D.B., 1955. Multiple range and multiple F tests. Biometrics, 11, 141. https://doi.org/10.2307/3001478.

Eadie, J.M., Hobson, P.N., and Mann, S.O., 1967. A note on some comparisons between the rumen content of barley fed steers and that of young calves also fed on high concentrate rations. J. Anim. Prod., 9(2), 247-250. https://doi.org/10.1017/S0003356100038514.

France, J, Dijkstra, J, Dhanoa, M.S., López, S., and Bannink, A., 2000. Estimating the extent of degradation of ruminant feeds from a description of their gas production profiles observed in vitro: derivation of models and other mathematical considerations. Br. J Nutr., 83:143150. https://doi.org/10.1017/S0007114500000180.

Giannenas, I., Skoufos, J., Giannakopoulos, C., Wiemann, M., Gortzi, O., Lalas, S., and Kyriazakis, I., 2011. Effects of essential oils on milk production, milk composition, and rumen microbiota in Chios dairy ewes. Journal of Dairy Science, 94(11), 5569-5577. https://doi.org/10.3168/jds.2010-4096.

Giller, K., Rilko, T., Manzocchi, E., Hug, S., Bolt, R.,and Kreuzer, M., 2020. Effects of mixed essential oils from eucalyptus, thyme and anise on composition, coagulation properties and antioxidant capacity of the milk of dairy cows. Journal of Animal and Feed Sciences, 29(1), 3-

10. https://doi.org/10.22358/jafs/118208/2020.

Goering, H. K., and Van Soest, P. J., 1970. Forage fiber analysis. Agricultural handbook no. 379. US Department of Agriculture, Washington, DC., 1-20.

Huang, C.M., and Lee, T.T., 2018. Immunomodulatory effects of phytogenics in chickens and pigs- A review. Asian-Australasian Journal of Animal Sciences, 31(5), 617627. https://doi.org/10.5713/ajas.17.0657.

Kearl, L.C., 1982. Nutrient requirements of ruminants in developing Countries International Feed Stuffs Institute, Utah Agriculture Experimental Station, Utah State University, Logan Utah, USA. In Option Mediterranean's, series A, No 67, P271, CIHEAM, Paris. 
Lammari, N., Louaer, O., Meniai, A.H., and Elaissari, A., 2020. Encapsulation of essential oils via nanoprecipitation process: Overview, progress, challenges and prospects. Pharmaceutics, 12(5), 431. https://doi.org/10.3390/pharmaceutics12050431.

Maes, C., Bouquillon, S., and Fauconnier, M. L., 2019. Encapsulation of essential oils for the development of biosourced pesticides with controlled release: A review. Molecules, 24(14), 2539. https://doi.org/10.3390/molecules24142539.

Malekkhahi, M., Tahmasbi, A.M., Naserian, A.A., Danesh Mesgaran, M., Kleen, J., and Parand, A., 2015. Effects of essential oils, yeast culture and malate on rumen fermentation, blood metabolites, growth performance and nutrient digestibility of Baluchi lambs fed high-concentrate diets. J. Anim. Physiol. Anim. Nutr., 99, 221-229. https://doi.org/10.1111/jpn.12230.

Manh, N. S., Wanapat, M., Uriyapongson, S., Khejornsart, P., and Chanthakhoun, V., 2012. Effect of eucalyptus (Camaldulensis) leaf meal powder on rumen fermentation characteristics in cattle fed on rice straw. African Journal of Agricultural Research, 7(14), 2142-2148. https://doi.org/10.5897/AJAR11.1347.

McIntosh, F.M., Williams, P., Losa, R., Wallace, R.J., Beever, D.A., and Newbold, C.J., 2003. Effects of essential oils on ruminal microorganisms and their protein metabolism. Appl Environ Microbiol, 69,50115014. https://doi.org/10.1128/AEM.69.8.5011-5014.2003.

Morsy, T., Kholif, S., Matloup, O., Abdo, M., and El-Shafie, M., 2012. Impact of anise, clove and juniper oils as feed additives on the productive performance of lactating goats. Int. J. Dairy Sci., 7, 2028. https://doi.org/10.3923/ijds.2012.20.28.

Nguyen, H., Campi, E.M., Jackson, W.R., and Patti, A.F. 2009. Effect of oxidative deterioration on flavour and aroma components of lemon oil. Food Chem., 112, 388393. https://doi.org/10.1016/j.foodchem.2008.05.090.

Patra, A.K., and Yu, Z., 2012. Effects of essential oils on methane production and fermentation by, and abundance and diversity of, rumen microbial populations. Appl. Environ. Microbial, 78, 42714280. https://doi.org/10.1128/AEM.00309-12.

Pellikaan, W.F., Hendriks, W.H., Uwimana, G., Bongers, L.J.G.M., Becker, P.M., and Cone, J. W., 2011. A novel method to determine simultaneously methane production during the in vitro gas production using fully automated equipment. Anim. Feed Sci. Technol., 168:196205. https://doi.org/10.1016/j.anifeedsci.2011.04.096.

Raafat, N. A., and Saleh, M. S., 1962. Two formulas for the conversion of cows and buffaloes milk different fat percentage. Proceedings of the $1^{\text {st }}$ Animal Production Conferences (APC62), Minia, p. 203.

Sallam, S. M., Bueno, I. C., Nasser, M. E., and Abdalla, A. L., 2010. Effect of eucalyptus (Eucalyptus citriodora) fresh or residue leaves on methane emission in vitro. Italian Journal of Animal Science, 9(3), 
e58. https://doi.org/10.4081/ijas.2010.e58.

Santos, M.B., Robinson P.H., Williams P., and Losa R., 2010. Effects of addition of an essential oil complex to the diet of lactating dairy cows on whole tract digestion of nutrients and productive performance. Anim. Feed Sci. Technol., 157, 64-71, https://doi.org/10.1016/j.anifeedsci.2010.02.001.

Schneider, B. H., and Flatt, W. P., 1975. The evaluation of feeds through digestibility experiments. The University of Georgia Press Athens, 30602.

Sebei, K., Sakouhi, F., Herchi, W., Khouja, M.L., Boukhchina, S., 2015. Chemical composition and antibacterial activities of seven Eucalyptus species essential oils leaves. Biol. Res., 48, 7, https://doi.org/10.1186/0717-6287-48-7.

Thao, N. T., Wanapat, M., Cherdthong, A., and Kang, S., 2014. Effects of eucalyptus crude oils supplementation on rumen fermentation, microorganism and nutrient digestibility in swamp buffaloes. Asian-Australasian Journal of Animal Sciences, 27(1), 46. https://doi.org/10.5713/ajas.2013.13301.

Thao, N.T., Wanapat, M., Kang, S., and Cherdthong, A., 2015. Effects of supplementation of eucalyptus ( $E$. camaldulensis) leaf meal on feed intake and rumen fermentation efficiency in swamp buffaloes. AsianAustralasian Journal of Animal Sciences, 28(7), 951. https://doi.org/10.5713/ajas.14.0878.

Theodorou, M.K., Williams, B.A., Dhanoa, M.S., McAllan, A.B., and France, J. A., 1994. Simple gas production method using a pressure transducer to determine the fermentation kinetics of ruminant feeds. Anim. Feed Sci. Technol., 48, 185-197. https://doi.org/10.1016/0377-8401(94)90171-6.

Turek, C., and Stintzing, F. C., 2013. Stability of essential oils: a review. Comprehensive reviews in food science and food safety, 12(1), 40-53. https://doi.org/10.1111/1541-4337.12006.

Vakili, A.R., Khorrami, B., Mesgaran, M.D., and Parand, E., 2013. The effects of thyme and cinnamon essential oils on performance, rumen fermentation and blood metabolites in Holstein calves consuming high concentrate diet. Asian-Australasian Journal of Animal Sciences, 26(7), 935944. https://doi.org/10.5713/ajas.2012.12636.

Van Keulen, J., and Young, B.A., 1977. Evaluation of acid-insoluble ash as a natural marker in ruminant digestibility studies. J Anim Sci., 44, 282-287. https://doi.org/10.2527/jas1977.442282x.

Van Soest, P.V., Robertson, J.B., and Lewis, B.A., 1991. Methods for dietary fiber, neutral detergent fiber, and nonstarch polysaccharides in relation to animal nutrition. Journal of Dairy Science, $74(10), 3583-$ 3597. https://doi.org/10.3168/jds.S0022-0302(91)78551-2.

Wall, E.H., Doane, P. H., Donkin, S.S., and Bravo, D., 2014. The effects of supplementation with a blend of cinnamaldehyde and eugenol on feed intake and milk production of dairy cows. Journal of Dairy Science, 97(9), 5709-5717. http://dx.doi.org/10.3168/jds.2014-7896. 
Wanapat, M., Ngarmsang, A., Korkhuntot, S., Nontaso, N., Wachirapakorn, C., Beakes, G., and Rowlinson, P.A., 2000. comparative study on the rumen microbial population of cattle and swamp buffalo raised under traditional village conditions in the northeast of Thailand. Asian-Australasian Journal of Animal Sciences, 13(7), 918-921. https://doi.org/10.5713/ajas.2000.918.

Wang, C.J., Wang, S.P., and Zhou, H., 2009. Influences of flavomycin, ropadiar, and saponin on nutrient digestibility, rumen fermentation, and methane emission from sheep. Anim. Feed Sci. Technol., 148, 157-166. https://doi.org/10.1016/j.anifeedsci.2008.03.008.

Yang, W.Z., Ametaj, B.N., Benchaar, C., and Beauchemin, K.A., 2010a. Dose response to cinnamaldehyde supplementation in growing beef heifers: ruminal and intestinal digestion. J Anim Sci., 88, 680688. https://doi.org/10.2527/jas.2008-1652.

Yang, W.Z., Ametaj, B.N., He, M.L., Benchaar, C., and Beauchemin, K.A., 2010b. Cinnamaldehyde in feedlot cattle diets: intake, growth performance, carcass characteristics, and blood metabolites. J Anim Sci., 88:1082-1092. https://doi.org/10.2527/jas.2008-1608.

\section{Tables}

Table (1): Chemical composition of ingredients and the experimental diet (\%) on a DM basis.

\begin{tabular}{llllllllllll} 
Item & \multicolumn{1}{l}{ Ingredients } & & & \multicolumn{5}{c}{ Experimental diets } \\
\cline { 2 - 11 } & CFM & BF & RS & CS & EUL & EUS & $G_{1}$ & $G_{2}$ & $G_{3}$ & $G_{4}$ \\
\hline OM & 91.06 & 86.97 & 83.18 & 92.11 & 95.07 & 94.93 & 88.09 & 88.76 & 88.76 & 88.09 \\
\hline CP & 16.35 & 15.07 & 2.69 & 8.62 & 8.63 & 12.94 & 12.28 & 12.37 & 12.34 & 12.28 \\
\hline NDF & 55.65 & 34.78 & 73.41 & 60.00 & 60.82 & 62.01 & 53.78 & 54.21 & 54.20 & 53.78 \\
\hline ADF & 38.26 & 23.91 & 48.64 & 45.64 & 50.01 & 51.82 & 36.86 & 37.22 & 37.21 & 36.86 \\
\hline EE & 3.62 & 2.34 & 1.19 & 2.58 & 5.92 & 7.85 & 2.60 & 2.89 & 2.86 & 2.90 \\
\hline Ash & 8.94 & 13.03 & 16.82 & 7.89 & 4.93 & 5.07 & 11.91 & 11.24 & 11.24 & 11.91
\end{tabular}

CFM concentrate feed mixture; $B F$ fresh berseem; $R S$ rice straw; $C S$ corn silage; $E U L$ eucalyptus leaves; EUS eucalyptus seeds; EUO eucalyptus oil; OM organic matter; $C P$ crude protein; NDF neutral detergent fibre; $A D F$ acid detergent fibre; SEM standard error of the mean; $E E$ ether extract. 
Table (2): Effect of leaves, seeds, and eucalyptus oil supplementation on in vitro cumulative gas, methane production, and NDF degradability.
Treatments
$\mathbf{G}_{1}$
$\mathrm{G}_{2}$
$\mathbf{G}_{3}$
$\mathbf{G}_{4}$
SEM
P-value

Basis pattern of in vitro fermentation

\begin{tabular}{lllllll}
$\mathrm{pH}$ & $5.99^{\mathrm{b}}$ & $6.05^{\mathrm{b}}$ & $6.07^{\mathrm{b}}$ & $6.25^{\mathrm{a}}$ & 0.037 & 0.0018 \\
$\mathrm{NH}_{3}-\mathrm{N}(\mathrm{mg} / \mathrm{L})$ & $183.7^{\mathrm{a}}$ & $182.55^{\mathrm{a}}$ & $182.04^{\mathrm{a}}$ & $163.61^{\mathrm{b}}$ & 5.150 & 0.0522 \\
\hline SCFA's $(\mathrm{mM} / \mathrm{L})$ & $89.02^{\mathrm{a}}$ & $88.98^{\mathrm{a}}$ & $88.86^{\mathrm{a}}$ & $83.55^{\mathrm{b}}$ & 0.695 & 0.0002 \\
\hline Acetic acid (mol/100 mol) & $59.99^{\mathrm{a}}$ & $59.95^{\mathrm{a}}$ & $59.93^{\mathrm{a}}$ & $57.22^{\mathrm{b}}$ & 0.728 & 0.0484 \\
\hline Propionic acid (mol/100 mol) & $20.83^{\mathrm{b}}$ & $21.53^{\mathrm{a}}$ & $21.54^{\mathrm{a}}$ & $19.99^{\mathrm{c}}$ & 0.252 & 0.0027 \\
\hline Butyric acid (mol/100 mol) & $11.77^{\mathrm{b}}$ & $11.68^{\mathrm{b}}$ & $12.23^{\mathrm{a}}$ & $11.26^{\mathrm{c}}$ & 0.080 & $<.0001$ \\
$\mathrm{C}_{2} / \mathrm{C}_{3}$ ratio & $2.88^{\mathrm{a}}$ & $2.78^{\mathrm{b}}$ & $2.78^{\mathrm{b}}$ & $2.86^{\mathrm{a}}$ & 0.016 & 0.0013
\end{tabular}

\section{Ruminal Microorganisms}

Bacteria counts, $\times 10^{6} \mathrm{cfu} / \mathrm{mL}$

$6.48^{\mathrm{a}}$

$6.42^{\mathrm{a}}$

$6.37^{a}$

$6.07^{b}$

$0.035<.0001$

CB count, $\times 10^{5} \mathrm{cfu} / \mathrm{mL}$

$2.92^{\mathrm{a}}$

$2.89^{a b}$

$2.87^{b}$

$2.73^{\mathrm{c}}$

$0.016<.0001$

Protozoa counts, $\times 10^{3} \mathrm{cfu} / \mathrm{mL}$

$3.64^{b}$

$3.67^{b}$

$3.68^{\mathrm{b}}$

$3.83^{a}$

0.026

0.0016

\section{Kinetic of gas production}

\begin{tabular}{lcccccc}
$\mathrm{A}$ & $103.03^{\mathrm{a}}$ & $98.00^{\mathrm{b}}$ & $97.93^{\mathrm{b}}$ & $77.70^{\mathrm{c}}$ & 0.500 & $<.0001$ \\
$\mathrm{~B}$ & $0.051^{\mathrm{ab}}$ & $0.050^{\mathrm{b}}$ & $0.050^{\mathrm{b}}$ & $0.053^{\mathrm{a}}$ & 0.001 & 0.0346 \\
$\mathrm{C}$ & $-0.155^{\mathrm{b}}$ & $-0.152^{\mathrm{b}}$ & $-0.156^{\mathrm{b}}$ & $-0.099^{\mathrm{a}}$ & 0.007 & 0.0002 \\
$\mathrm{~L}$ & $2.332^{\mathrm{a}}$ & $2.286^{\mathrm{a}}$ & $2.481^{\mathrm{a}}$ & $0.978^{\mathrm{b}}$ & 0.186 & 0.0003 \\
$\mathrm{CH}_{4}(\mathrm{ml} / \mathrm{g} \mathrm{DM})$ & $14.10^{\mathrm{a}}$ & $8.41^{\mathrm{b}}$ & $8.35^{\mathrm{b}}$ & $8.35^{\mathrm{b}}$ & 0.142 & $<.0001$ \\
\hline $\mathrm{ME}(\mathrm{MJ} / \mathrm{kg} \mathrm{DM})$ & $11.664^{\mathrm{a}}$ & $10.513^{\mathrm{b}}$ & $10.449^{\mathrm{b}}$ & $9.685^{\mathrm{c}}$ & 0.098 & $<.0001$ \\
\hline IVNDFD (\%) & $45.41^{\mathrm{a}}$ & $43.25^{\mathrm{b}}$ & $42.82^{\mathrm{b}}$ & $40.00^{\mathrm{c}}$ & 0.237 & $<.0001$
\end{tabular}

abc, Means within the same rows with differing superscripts are significantly different $(P \leq 0.05)$.

$S E M$ standard error of the mean; $C B$ cellulolytic bacteria; $A$ the exponential total gas $\mathrm{mL} ; B$ the asymptotic gas produced $(\mathrm{mL} / \mathrm{g} \mathrm{DM})$ by the insoluble but slowly fermenting fraction; $C$ constant gas production rate $(\mathrm{mL} / \mathrm{h}) ; \mathrm{L}$ lag time; IVNDFD In vitro neutral detergent fiber degradability 
Table (3): Effect of leaves, seeds, and eucalyptus oil supplementation on milk production, its constituents, and feed conversion.

Item Experimental diets

$G_{1} \quad G_{2}$
SEM P-value

$\mathbf{G}_{4}$
$\operatorname{TxP}$

0.7791

0.6526

$\mathrm{MP}(\mathrm{kg} / \mathrm{h} / \mathrm{d})$

$7.00^{\mathrm{a}}$

$6.84^{\mathrm{b}}$

$6.80^{b}$

$6.54^{\mathrm{c}}$

$0.047<.0001$

0.8900

0.9926

0.9713

$\operatorname{FCM}(\mathrm{kg} / \mathrm{h} / \mathrm{d})$

$6.38^{a}$

$6.19^{\mathrm{b}}$

$6.10^{\mathrm{b}}$

$5.82^{\mathrm{c}}$

$0.059<.0001$

0.9969

0.8982

$8.78^{b} \quad 8.66^{b}$

$8.24^{\mathrm{c}}$

$0.068<.0001$

0.9969

\section{Milk composition (\%).}

\begin{tabular}{lllllllll}
\hline Fat & $6.16^{\mathrm{a}}$ & $6.08^{\mathrm{ab}}$ & $6.02^{\mathrm{ab}}$ & $5.95^{\mathrm{b}}$ & 0.060 & 0.1013 & 0.7209 & 0.6964 \\
\hline Protein & 3.78 & 3.78 & 3.77 & 3.69 & 0.031 & 0.2065 & 0.6721 & 0.8121 \\
\hline Lactose & $4.54^{\mathrm{b}}$ & $4.57^{\mathrm{ab}}$ & $4.66^{\mathrm{ab}}$ & $4.72^{\mathrm{a}}$ & 0.050 & 0.0612 & 0.3893 & 0.8416 \\
\hline Ash & 1.39 & 1.38 & 1.38 & 1.38 & 0.018 & 0.9647 & 0.9634 & 0.1685 \\
\hline SNF & 9.71 & 9.73 & 9.80 & 9.79 & 0.061 & 0.6439 & 0.2387 & 0.4375 \\
\hline TS & 15.87 & 15.82 & 15.82 & 15.74 & 0.071 & 0.6798 & 0.5617 & 0.9866
\end{tabular}

\section{Feed conversion (kg intake/kg FCM 7\% fat).}

TDMI/FCM

TDNI/FCM

NI/FCM $2.746^{a}$

0.032

0.019

$1.609^{a b}$

$0.054^{\mathrm{a}}$

0.001

$<.0001$

0.6758

0.5986

$1.563^{\mathrm{b}}$

abc

$0.049^{c}$

$0.052^{\mathrm{b}} \quad 0.053^{\mathrm{ab}}$

(2)

$\begin{array}{lll}0.0333 & 0.6652 & 0.5867\end{array}$

c, Means within the same rows with differing superscripts are significantly different $(P \leq 0.05)$.

SEM standard error of the mean, TDMI total dry matter intake; MP milk production; $F C M 7 \%$ fatcorrected milk; ECM energy-corrected milk; SNF solid not fat; TS total solids; NI nitrogen intake 
Table (4): Effect of leaves, seeds, and eucalyptus oil supplementation on apparent digestibility coefficients and blood parameters of experimental diets.
Item
Experimental diets
$\stackrel{ \pm}{\text { SEM } \quad p \text {-Value }}$
$\begin{array}{llll}G_{1} & G_{2} & G_{3} & G_{4}\end{array}$
P TXP

Nutrient digestibility and Nutritive values (\%).

\begin{tabular}{lcccccccc} 
DM & $66.63^{\mathrm{a}}$ & $65.86^{\mathrm{a}}$ & $63.88^{\mathrm{b}}$ & $61.73^{\mathrm{c}}$ & 0.358 & $<.0001$ & 0.3414 & 0.4809 \\
\hline OM & $68.41^{\mathrm{a}}$ & $67.60^{\mathrm{b}}$ & $66.41^{\mathrm{c}}$ & $63.51^{\mathrm{d}}$ & 0.107 & $<.0001$ & 0.0101 & $<.0001$ \\
\hline $\mathrm{CP}$ & $70.62^{\mathrm{a}}$ & $69.43^{\mathrm{b}}$ & $67.33^{\mathrm{c}}$ & $63.03^{\mathrm{d}}$ & 0.131 & $<.0001$ & 0.1097 & 0.1292 \\
\hline EE & $67.15^{\mathrm{c}}$ & $76.07^{\mathrm{a}}$ & $75.25^{\mathrm{a}}$ & $73.08^{\mathrm{b}}$ & 0.462 & $<.0001$ & 0.7607 & 0.8997 \\
\hline NDF & $68.11^{\mathrm{a}}$ & $67.28^{\mathrm{b}}$ & $64.24^{\mathrm{c}}$ & $60.01^{\mathrm{d}}$ & 0.209 & $<.0001$ & 0.0409 & $<.0001$ \\
\hline ADF & $62.59^{\mathrm{a}}$ & $62.05^{\mathrm{b}}$ & $59.36^{\mathrm{c}}$ & $57.40^{\mathrm{d}}$ & 0.127 & $<.0001$ & $<.0001$ & $<.0001$ \\
\hline TDN & $62.45^{\mathrm{a}}$ & $62.75^{\mathrm{a}}$ & $61.63^{\mathrm{b}}$ & $58.60^{\mathrm{c}}$ & 0.093 & $<.0001$ & 0.0109 & $<.0001$ \\
\hline DCP & $8.67^{\mathrm{a}}$ & $8.55^{\mathrm{b}}$ & $8.31^{\mathrm{c}}$ & $7.74^{\mathrm{d}}$ & 0.016 & $<.0001$ & 0.1179 & 0.1125
\end{tabular}

\section{Blood parameters}

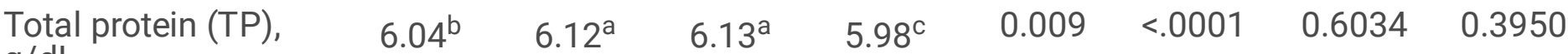
$\mathrm{g} / \mathrm{dL}$

$\begin{array}{lcccccccc}\text { Albumin (A), g/dL } & 3.04^{\mathrm{b}} & 3.15^{\mathrm{a}} & 3.15^{\mathrm{a}} & 3.00^{\mathrm{b}} & 0.027 & 0.0003 & 0.7482 & 0.0150 \\ \text { AST, u/L } & 36.38^{\mathrm{b}} & 36.47^{\mathrm{b}} & 36.56^{\mathrm{b}} & 37.56^{\mathrm{a}} & 0.314 & 0.0394 & 0.7197 & 0.9019 \\ \text { ALT, u/L } & 16.06^{\mathrm{b}} & 16.10^{\mathrm{b}} & 16.16^{\mathrm{b}} & 16.59^{\mathrm{a}} & 0.145 & 0.0508 & 0.6927 & 0.0003 \\ \text { Urea (BUN), mg/dL } & 15.39^{\mathrm{a}} & 15.22^{\mathrm{a}} & 15.23^{\mathrm{a}} & 14.10^{\mathrm{b}} & 0.073 & <.0001 & 0.1348 & 0.1178 \\ \text { Glucose, mg/dL } & 58.50^{\mathrm{d}} & 61.80^{\mathrm{c}} & 63.73^{\mathrm{b}} & 65.23^{\mathrm{a}} & 0.120 & <.0001 & 0.2217 & 0.1760 \\ \text { Creatinine, mg/dL } & 1.52^{\mathrm{b}} & 1.50^{\mathrm{b}} & 1.57^{\mathrm{a}} & 1.58^{\mathrm{a}} & 0.014 & 0.0003 & 0.0334 & 0.1999\end{array}$

abc, Means within the same rows with differing superscripts are significantly different $(P \leq 0.05)$.

$S E M$ standard error of the mean; $D M$ dry matter; $O M$ organic matter; $C P$ crude protein; $E E$ ether extract; $N D F$ neutral detergent fibre; $A D F$ acid detergent fibre; $T D N$ total digestible nutrient; $D C P$ digestible crude protein; $A S T$ aspartate aminotransferase; $A L T$ alanine aminotransferase

\section{Figures}




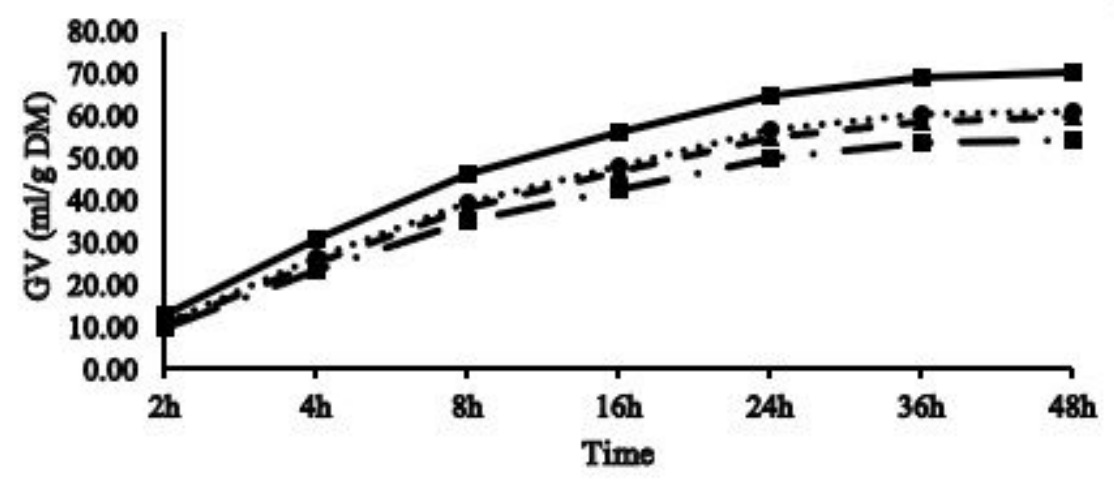

$\rightarrow$ Control $\cdots \bullet \cdot$ EUS $\longrightarrow$ - EUL $\rightarrow \cdot$ EUO

\section{Figure 1}

Cumulative gas volume $(\mathrm{Gv}(\mathrm{t}))$ for the experimental diets at different incubation times 